\title{
Milk production and nutrient digestibility by dairy cows when fed exogenous amylase with coarsely ground dry corn
}

\author{
W. P. Weiss, ${ }^{\star 1}$ W. Steinberg, $\nmid$ and M. A. Engstrom $\neq$ \\ *Department of Animal Sciences, Ohio Agricultural Research and Development Center, The Ohio State University, Wooster 44691 \\ †DSM Nutritional Products Ltd., Basel, Switzerland $\mathrm{CH}-4002$ \\ ‡DSM Nutritional Products Inc., Parsippany, NJ 07054
}

\section{ABSTRACT}

The digestibility of starch provided by coarsely ground corn is often low, which reduces the digestible energy (DE) concentration of the diet. We hypothesized that adding exogenous amylase to diets based on coarsely ground dent corn would increase dietary DE resulting in greater milk production. Total-tract nutrient digestibility was measured in a partially replicated Latin square experiment ( 6 cows and 4 periods) with a $2 \times 2$ factorial arrangement of treatments. Diets had 26 or $31 \%$ starch with or without exogenous amylase (amylase was added to the concentrate mixes at the feed mill). In the low and high starch diets, coarsely ground dry corn (mean particle size $=1.42 \mathrm{~mm}$ ) provided 43 and $62 \%$ of total dietary starch (corn silage provided most of the remaining starch). No treatment interactions were observed. High starch diets had greater dry matter (DM), organic matter, and energy digestibility than low starch diets, and diets with amylase had greater neutral detergent fiber digestibility than diets without amylase. Digestibility of starch averaged $88 \%$ and was not affected by treatment. A long-term (98-d) lactation study with 48 Holstein cows (74 d in milk) was conducted using 3 of the diets (low starch diets with and without amylase and the high starch diet without amylase). Addition of amylase to a diet with $26 \%$ starch did not affect intake, milk yield, milk composition, body weight, or body condition. Cows fed the diet with $31 \%$ starch had greater DM and DE intakes; yields of milk, fat, and protein; and feed efficiency than those fed diets with $26 \%$ starch. Milk composition was not affected by starch concentration. Adding exogenous amylase to a lower starch diet did not make the diet nutritionally equivalent to a higher starch diet.

Key words: amylase, starch, digestibility, corn

Received August 27, 2010.

Accepted January 15, 2011.

${ }^{1}$ Corresponding author: weiss.6@osu.edu

\section{INTRODUCTION}

Starch is a major constituent of many diets for lactating cows and it can be an economical source of digestible energy (DE). Numerous factors affect totaltract starch digestibility, resulting in a wide range in reported digestibility coefficients (Firkins et al., 2001). A major factor affecting digestibility of starch is the size of the starch particle, especially when dry corn grain is the starch source (Wilkerson et al., 1997; Firkins et al., 2001). Decreasing the particle size of corn usually improves starch digestibility; however, the time and energy required to process corn increases as the particle size of the resulting product decreases (Reece et al., 1986). The increased processing costs must be balanced against the increase in nutritional value of the corn.

Exogenous enzymes may be an alternative to extensive physical processing of corn. The addition of exogenous enzymes with fibrolytic activity to dairy cow diets has increased the digestibility of DM, NDF, and CP (Rode et al., 1999; Yang et al., 1999; Bowman et al., 2002). Addition of various exogenous amylase to ruminant diets has often increased total-tract DM digestibility (Rojo et al., 2005; Klingerman et al., 2009; Gencoglu et al., 2010) but effects on total-tract starch digestibility have been inconsistent and usually not significant (Rojo et al., 2005; Hristov et al., 2008; Klingerman et al., 2009; Gencoglu et al., 2010). Most papers described the primary starch source (dry corn or sorghum) simply as ground [Hristov et al. (2008) used dry-rolled corn], but Gencoglu et al. (2010) reported particle size of the grain $(0.7 \mathrm{~mm})$. Starch from finely ground corn is usually highly digestible; therefore, any additional improvement by exogenous amylase may be limited.

We hypothesized that adding an exogenous amylase would increase in vivo starch digestibility when coarsely ground corn is fed. This could result in a lower starch diet having similar nutritional value as a higher starch diet that did not include amylase. To test this hypothesis we conducted 2 experiments with the following objectives: (1) to determine whether adding amylase to 
Table 1. Ingredient and nutrient composition of experimental diets (\% of DM unless otherwise noted)

\begin{tabular}{|c|c|c|c|c|}
\hline \multirow[b]{2}{*}{ Item } & \multicolumn{2}{|c|}{ Low starch } & \multicolumn{2}{|c|}{ High starch } \\
\hline & - Amylase & + Amylase & - Amylase & + Amylase \\
\hline \multicolumn{5}{|l|}{ Ingredient } \\
\hline Corn silage & 40.0 & 40.0 & 30.0 & 30.0 \\
\hline Alfalfa silage & 20.0 & 20.0 & 20.0 & 20.0 \\
\hline Corn grain, coarse grind ${ }^{1}$ & 15.3 & 15.175 & 26.3 & 26.175 \\
\hline Soybean meal, $44 \%$ CP & 6.1 & 6.1 & 6.8 & 6.8 \\
\hline Treated soybean meal ${ }^{2}$ & 4.8 & 4.8 & 4.1 & 4.1 \\
\hline Soybean hulls & 7.6 & 7.6 & 6.6 & 6.6 \\
\hline Dried distillers with solubles & 4.0 & 4.0 & 4.0 & 4.0 \\
\hline Animal-vegetable fat & 0.4 & 0.4 & 0.4 & 0.4 \\
\hline Mineral/vitamin $\operatorname{mix}^{3}$ & 1.8 & 1.8 & 1.8 & 1.8 \\
\hline Enzyme $^{4}$ & - & 0.125 & - & 0.125 \\
\hline \multicolumn{5}{|l|}{ Nutrient composition of $\mathrm{TMR}^{5}$} \\
\hline $\mathrm{CP}, \%$ & 14.9 & 15.0 & 15.4 & 15.1 \\
\hline Starch, \% & 26.0 & 25.7 & 30.6 & 31.6 \\
\hline NDF, $\%$ & 39.0 & 38.4 & 35.3 & 36.2 \\
\hline Forage NDF, \% & 27.1 & 27.1 & 23.0 & 23.0 \\
\hline Gross energy, Mcal/kg & 4.34 & 4.33 & 4.34 & 4.35 \\
\hline
\end{tabular}

${ }^{1}$ Mean particle size $=1.42 \mathrm{~mm}(\mathrm{n}=5$ samples $)$.

${ }^{2}$ Nonenzymatically browned soybean meal (SurePro, Land O'Lakes Inc., St. Paul, MN).

${ }^{3}$ Mix contained $448 \mathrm{~g}$ of limestone, $337 \mathrm{~g}$ of trace mineral salt, $45 \mathrm{~g}$ of dicalcium phosphate, $22 \mathrm{~g}$ of magnesium oxide, $1.2 \mathrm{~g}$ of $\mathrm{Zn}$ (from zinc sulfate), $0.4 \mathrm{~g}$ of copper (from copper sulfate), $16 \mathrm{mg}$ of Se (from sodium selenate), $44 \mathrm{mg}$ of biotin, $268 \mathrm{kIU}$ of vitamin A, $54 \mathrm{kIU}$ of vitamin D, and 1,400 IU of vitamin $\mathrm{E} / \mathrm{kg}$.

${ }^{4}$ Liquid amylase solution (Ronozyme RumiStar L, DSM Nutritional Products, Basel, Switzerland and Novozymes, Bagsvaerd, Denmark) with an amylase activity of 240 kilo Novo units/g.

${ }^{5}$ Nutrient concentrations of TMR were calculated from assayed concentrations of the concentrate mix and the forages.

a concentrate mix based on coarsely ground corn would enhance in vivo digestibility of nutrients when fed to lactating dairy cows, and (2) to determine whether cows fed a low starch diet with added amylase would have similar production as cows fed a higher starch diet without added enzyme.

\section{MATERIALS AND METHODS}

All procedures involving animals were approved by the Ohio State University Agricultural Animal Care Committee. The 2 studies ran concurrently.

\section{Digestibility Experiment}

Eight multiparous Holstein cows $(104 \pm 13$ DIM at the start of the experiment) were used in 2 orthogonal replicated $4 \times 4$ Latin squares with 24 -d periods. Treatments consisted of low and high concentration of starch each with and without amylase (Table 1). A liquid amylase formulation, Ronozyme RumiStar L (DSM Nutritional Products, Basel, Switzerland, and Novozymes, Bagsvaerd, Denmark), was added to the concentrate mix at a rate (target was 300 kilo Novo units $(\mathbf{K N U}) / \mathrm{kg}$ of TMR DM) shown to be effective in previous studies (Klingerman et al., 2009; Gencoglu et al., 2010). During the experiment, the enzyme was stored in a refrigerator $\left(4^{\circ} \mathrm{C}\right)$ until it was mixed into the concentrate at the feed mill. The concentrate with the enzyme was stored in conventional feed bags in a dry location at ambient temperature (experiment was conducted between October and May). Concentrate not used within $14 \mathrm{~d}$ of mixing was discarded. The primary starch source in all diets was coarsely ground corn (mean particle size $=1.42 \mathrm{~mm}$ ). By comparison, the average mean particle size of dry corn samples from dairy farms submitted to a commercial laboratory $(\mathrm{n}=$ 318) was $0.85 \mathrm{~mm}$ (Dave Taysom, Dairyland Laboratories Inc., Arcadia, WI; personal communication).

Cows were housed in individual tie stalls and fed once daily with the amounts of feed offered and refused recorded (orts averaged $3.5 \%$ of the amount offered). Cows were milked twice daily and yields recorded electronically. Milk (a.m. and p.m.) was sampled once weekly and analyzed for milk fat, protein, lactose (B2000 Infrared Analyzer, Bentley Instruments, Chaska, MN), and MUN (Skalar SAN Plus segmented flow analyzer, Skalar Inc., Norcross, GA) by DHI Cooperative Inc. (Columbus, OH). Cows were weighed on the first day of the experiment and on the last day of each period approximately $2 \mathrm{~h}$ after feeding. During the last week of each period, 6 cows (selected at the start of the experiment) were moved to specially designed stalls and output of urine and feces was measured for 
$4 \mathrm{~d}$ (Weiss et al., 2009). Urine, milk, orts, and feeds were sampled daily (kept refrigerated) and composited (within cow) over the $4 \mathrm{~d}$. Cows were then moved back to regular tie stalls and the process repeated for each period. Urine, milk, and wet feces samples were assayed for $\mathrm{N}$ within a few hours of the conclusion of each collection period. Lyophilized samples of silages, orts, and feces, and samples of concentrate mixtures were ground and assayed for DM, NDF, starch, and $\mathrm{N}$ as described below (lyophilized feces were not assayed for N), and gross energy (oxygen bomb calorimeter, model 1281, Parr Instruments, Moline, IL).

Production data collected during the digestion experiment were averaged over the last $10 \mathrm{~d}$ of each period and analyzed statistically with Proc MIXED (SAS Institute, 2004). One cow died during period 2 from acute coliform mastitis and no data from that cow were used, resulting in an unbalanced square. The model included cow (6 df, random), period (3 df, random), starch concentration (1 df, fixed), enzyme addition (1 df, fixed), starch by enzyme interaction (1 df, fixed), and error (15 df). Digestibility data were analyzed using the same model but collected from only 6 cows per period, so the cow term in the statistical model had only $5 \mathrm{df}$ and error had $12 \mathrm{df}$.

\section{Production Study}

Holstein cows (averaged $74 \pm 7$ DIM at the start of the experiment) were grouped by parity (first vs. all others) and calving date into 16 blocks of 3 animals (2 blocks of first parity). Only 3 of the 4 treatments used in the digestibility study were used in this study (low starch, low starch plus amylase, and high starch; Table $1)$. Cows were moved to tie stalls and fed a preliminary diet (50:50 mix of the low and high starch diets without amylase for $7 \mathrm{~d}$ and then fed their assigned treatment diet for the following $98 \mathrm{~d}$. Cows were weighed approximately $2 \mathrm{~h}$ after feeding on $\mathrm{d} 1$ of the experiment and every 2 wk until the end of the experiment. Body condition score $(1=$ emaciated, $5=$ obese $)$ was determined by 3 independent evaluators during the preliminary period and at approximately d 30,60, and 90 of the experiment. Backfat thickness was measured in the sacral region using ultrasound (Schröder and Staufenbiel, 2006) at the same time as BCS was determined. Backfat thickness was the average of 3 independent readings for each cow at each time point.

Silages were sampled weekly and analyzed for DM $\left(100^{\circ} \mathrm{C}\right.$ oven, overnight) to adjust inclusion rates for moisture changes and to calculate DMI. A subsample was retained in the freezer and composited by month. Samples of the concentrate mixes were taken weekly and composited by month. Approximately every $5 \mathrm{wk}$, feed mill personnel sampled the ground corn and the freshly made concentrate mixes $(\mathrm{n}=5$ for corn and concentrate mixes). Particle size of the corn grain was measured (Kerley et al., 1985), and the concentrate samples were assayed for amylase activity (method AMY-101/01E; DSM Nutritional Products Analytical Research Center, Basel, Switzerland). Monthly composite samples of silage were lyophilized and samples of silage and concentrates were ground through a 1-mm screen (Wiley mill, Arthur H. Thomas, Philadelphia, PA) and assayed for DM $\left(100^{\circ} \mathrm{C}\right.$ oven for 24 h), NDF (Ankom ${ }^{200}$ Fiber Analyzer, Ankom Technology, Fairport, NY) with sodium sulfite and amylase (Sigma A3306, Sigma Diagnostics, St. Louis, MO), CP (Kjeldahl $\mathrm{N} \times 6.25)$, ash (AOAC, 2000), and starch (Weiss and Wyatt, 2000). Orts were sampled from each cow once monthly and assayed for $\mathrm{DM}\left(100^{\circ} \mathrm{C}\right.$ oven $)$ to calculate daily DMI. Four additional subsamples of the silages (a composite of 8 or 9 weekly samples) were assayed for particle size distribution (Lammers et al., 1996) and 30-h in vitro NDF digestibility (Cumberland Valley Analytical Services, Hagerstown, MD).

Milk production and composition data and DMI were averaged over 14 -d periods ( 7 periods during the experiment). All data were analyzed with the same basic statistical model using Proc MIXED (SAS Institute, 2004). The model included block (random, 15 df), treatment (fixed, $2 \mathrm{df}$ ), period (repeated measure with 6 df for milk and DMI, 5 df for BW, and $2 \mathrm{df}$ for BCS and body fat thickness), period $\times$ treatment interaction (fixed, varying degrees of freedom depending on response variable), and error. If significant, response data collected during the preliminary period were included as a covariate in the statistical model for the same response variable measuring during the experiment. The covariate was significant $(P<0.05)$ for DMI, milk yield, and milk fat and protein yields and concentrations. Treatment means were separated using a protected least significant different test (PDIFF option) when treatment effect was significant $(P<0.05)$.

\section{RESULTS AND DISCUSSION}

The assayed amylase activity of the enzyme was 296 $\mathrm{KNU} / \mathrm{g}$, the assayed amylase activity for the concentrate mixes without enzyme was $<14 \mathrm{KNU} / \mathrm{kg}$ of DM, and that for the low and high starch concentrates with enzyme was 820 and $622 \mathrm{KNU} / \mathrm{kg}$ of DM. That equates to activity of $<5.5 \mathrm{KNU} / \mathrm{kg}$ of TMR DM for control treatments and 332 and $311 \mathrm{KNU} / \mathrm{kg}$ of TMR DM for the low and high starch with amylase diets. Assayed values were within $10 \%$ of targeted values (i.e., those used by Klingerman et al., 2009; Gencoglu et al., 2010). The concentration of $\mathrm{CP}$ in the corn silage and alfalfa 
Table 2. Composition of the silages (DM basis $)^{1}$

\begin{tabular}{lrc}
\hline Item & $\begin{array}{c}\text { Corn } \\
\text { silage }\end{array}$ & $\begin{array}{c}\text { Alfalfa } \\
\text { silage }\end{array}$ \\
\hline DM, \% & 34.5 & 40.3 \\
Ash, \% & 3.9 & 8.5 \\
CP, \% & 6.5 & 16.9 \\
NDF, \% & 42.5 & 51.2 \\
Lignin, \% & 2.4 & 7.8 \\
IVNDFD, \% of NDF & 52.1 & 40.9 \\
Starch, \% & 35.6 & 1.4 \\
Particle size distribution, ${ }^{2}$ \% of wet weight & & \\
Top, 1.9-cm holes & 5.7 & 2.3 \\
Middle, 0.8-cm holes & 63.4 & 56.6 \\
Pan & 30.9 & 41.1 \\
\hline
\end{tabular}

${ }^{1}$ Number of samples within each silage type were 4 for lignin, 30-h in vitro NDF digestibility (IVNDFD), and particle size, and 12 for all other assays.

${ }^{2}$ Measured using 2-screen separator (Lammers et al., 1996).

silage (Table 2) decreased shortly after the start of the experiment, resulting in lower than planned dietary $\mathrm{CP}$ concentrations (Table 1). Based on NRC (2001), these diets had adequate MP to support 39 to $43 \mathrm{~kg} / \mathrm{d}$ of milk (using treatment average DMI). This is approximately the milk yield obtained; therefore, MP may have been a limiting nutrient.

\section{Digestibility Experiment}

By design, the low starch diets had greater concentrations of forage NDF (Table 1), and an underlying hypothesis was that the amount of forage fiber in the low starch diet would restrict DMI because of digestive tract fill (Allen, 2000). The greater DMI and energy di- gestibility would allow cows on the high starch diets to consume more DE, resulting in greater milk yields. We also hypothesized that the addition of amylase would not affect DMI, but would increase DE intake because of greater energy digestibility. As hypothesized, DMI $(P<0.07)$ and digestibility of energy (as well as DM and $\mathrm{OM}$ digestibility) were greater $(P<0.05)$ for cows fed high starch diets than for those fed low starch diets (Tables 3 and 4). Total-tract digestibility of starch averaged about $88 \%$ compared with $50 \%$ for NDF (Table 4). Replacing the less digestible NDF with the more digestible starch accounts for essentially all the difference in DM, OM, and energy digestibility. The greater DMI and energy digestibility increased $(P<0.01) \mathrm{DE}$ intake by $4.8 \mathrm{Mcal} / \mathrm{d}$ for cows fed the high starch diets (Table 3). The increase in DE intake did not result in a statistical increase in milk yield in the short-term digestibility experiment (Table 4) but did in the longterm production study (discussed below, Table 5). Cows fed the high starch diets had greater $(P<0.05)$ yields and concentrations of milk protein than cows fed low starch diets.

The addition of enzyme did not affect any production measure in the digestibility experiment (Table 3 ) or the production study (Table 5, discussed below). Enzyme addition did not affect $(P>0.2)$ total-tract digestibility of DM, OM, energy, or starch (Table 4). In previous studies (Klingerman et al., 2009; Gencoglu et al., 2010), amylase did not affect starch digestibility by lactating dairy cows; however, starch digestibility was very high in the control treatments (approximately 95\%). In our experiment coarsely ground corn was used (mean par-

Table 3. Production measures of cows fed diets with different starch concentrations with and without added amylase (Latin square experiment) ${ }^{1}$

\begin{tabular}{|c|c|c|c|c|c|}
\hline \multirow[b]{2}{*}{ Item } & \multicolumn{2}{|c|}{ Low starch } & \multicolumn{2}{|c|}{ High starch } & \multirow[b]{2}{*}{ SEM } \\
\hline & - Amylase & + Amylase & - Amylase & + Amylase & \\
\hline $\mathrm{BW},{ }^{\mathrm{a}} \mathrm{kg}$ & 630 & 635 & 642 & 614 & 19.5 \\
\hline DMI, ${ }^{b} \mathrm{~kg} / \mathrm{d}$ & 23.7 & 24.4 & 25.5 & 24.8 & 0.84 \\
\hline DE intake, ${ }^{2, c} \mathrm{Mcal} / \mathrm{d}$ & 62.9 & 65.8 & 69.9 & 68.4 & 1.32 \\
\hline Milk, kg/d & 38.3 & 37.5 & 38.9 & 38.7 & 2.09 \\
\hline Milk fat, $\%$ & 3.9 & 3.87 & 3.9 & 3.82 & 0.29 \\
\hline Milk fat, $\mathrm{kg} / \mathrm{d}$ & 1.48 & 1.44 & 1.54 & 1.49 & 0.13 \\
\hline Milk protein, $\%$ & 2.73 & 2.78 & 2.85 & 2.94 & 0.075 \\
\hline Milk protein, ${ }^{\mathrm{c}} \mathrm{kg} / \mathrm{d}$ & 1.04 & 1.03 & 1.1 & 1.1 & 0.071 \\
\hline Milk lactose, $\%$ & 4.68 & 4.65 & 4.71 & 4.66 & 0.13 \\
\hline Milk lactose, $\mathrm{kg} / \mathrm{d}$ & 1.78 & 1.73 & 1.82 & 1.82 & 0.14 \\
\hline $\mathrm{MUN},{ }^{\mathrm{d}} \mathrm{mg} / \mathrm{dL}$ & 10.2 & 11.2 & 10.5 & 10.7 & 0.82 \\
\hline
\end{tabular}

${ }^{\text {a Starch }} \times$ enzyme interaction $(P<0.05)$.

${ }^{\mathrm{b}}$ Starch main effect $(P<0.07)$.

${ }^{\mathrm{c}}$ Starch main effect $(P<0.05)$.

${ }^{\mathrm{d}}$ Starch $\times$ enzyme interaction $(P<0.06)$.

${ }^{1} \mathrm{n}=28$ observations $(7$ cows $\times 4$ periods $)$.

${ }^{2}$ Digestible energy (DE) intake was calculated as individual DMI times treatment average measured DE concentration (Table 4). 
Table 4. Total-tract nutrient digestibility by cows fed diets with different starch concentrations with and without added amylase (Latin square experiment) ${ }^{1}$

\begin{tabular}{|c|c|c|c|c|c|}
\hline \multirow[b]{2}{*}{ Item } & \multicolumn{2}{|c|}{ Low starch } & \multicolumn{2}{|c|}{ High starch } & \multirow[b]{2}{*}{ SEM } \\
\hline & - Amylase & + Amylase & - Amylase & + Amylase & \\
\hline $\mathrm{DM}^{\mathrm{a}} \%$ & 62.5 & 63.1 & 64.2 & 64.3 & 0.57 \\
\hline $\mathrm{OM},{ }^{\mathrm{a}} \%$ & 63.2 & 63.8 & 64.9 & 64.9 & 0.58 \\
\hline Energy, $\%$ & 61.9 & 62.7 & 63.6 & 63.7 & 0.59 \\
\hline $\mathrm{NDF},{ }^{\mathrm{b}} \%$ & 49.2 & 51.2 & 50.1 & 50.7 & 1.33 \\
\hline Starch, \% & 88.4 & 88.1 & 86.9 & 87.8 & 0.77 \\
\hline $\mathrm{CP}, \%$ & 59.4 & 59.3 & 59.7 & 58.8 & 1.18 \\
\hline Digestible energy, ${ }^{a} \mathrm{Mcal} / \mathrm{kg}$ & 2.69 & 2.71 & 2.77 & 2.78 & 0.029 \\
\hline
\end{tabular}

${ }^{a}$ Starch main effect $(P<0.05)$.

${ }^{\mathrm{b}}$ Enzyme main effect $(P<0.07)$

${ }^{1} \mathrm{n}=24$ observations $(6$ cows $\times 4$ periods $)$.

ticle size $=1.42 \mathrm{~mm})$ and starch digestibility averaged $87.8 \%$. In comparison, starch digestibility by lactating dairy cows averaged $90.8 \%$ in a large experiment $(12$ diets) using diets based on finely ground corn grain (Weiss et al., 2009) and, in a review, Firkins et al. (2001) reported an average starch digestibility of $90.6 \%$ for a wide range of diets fed to lactating dairy cows. Even though starch digestibility of the control treatments was lower than average for diets based on ground corn, amylase did not enhance it (Table 4). Potential reasons for the lack of effect of amylase on total-tract starch digestibility include the following. First, low activity of the enzyme in the rumen. However, various amylases, including the product used in this experiment, have increased in vitro and in situ digestibility of DM and starch (Gutiérrez et al., 2005; Klingerman et al., 2009). Second, the enzyme may have increased ruminal digest- ibility of starch but intestinal digestibility compensated for those differences. However, another type of exogenous amylase (produced by Bacillus licheniformis) added to sorghum-based diets increased both ruminal and total-tract starch digestibility by sheep (Rojo et al., 2005). Finally, the particle size of the corn may have overwhelmed any effect of the enzyme.

The addition of the enzyme treatment increased NDF digestibility $(P<0.07)$. Previous studies with this enzyme also reported increased NDF digestibility (Klingerman et al., 2009; Gencoglu et al., 2010). In those studies, the increase in NDF digestibility was greater than what we observed (4 to 10 percentage units vs. 1.3 units). The difference in magnitude could have been caused in part by differences in treatment effects on DMI. In the 2 previous studies, cows fed amylase (in the low starch treatments) had reduced DMI, and the

Table 5. Effect of dietary starch concentration and amylase addition on production measures over $98 \mathrm{~d}$ (production experiment) $)^{1}$

\begin{tabular}{lcccc}
\hline Item & $\begin{array}{c}\text { Low } \\
\text { starch }\end{array}$ & $\begin{array}{c}\text { Low starch } \\
\text { amylase }\end{array}$ & $\begin{array}{c}\text { High } \\
\text { starch }\end{array}$ & SEM \\
\hline BW, kg & 686 & 659 & 663 & 13 \\
BW change, kg/d & 0.16 & 0.23 & 0.29 & 0.08 \\
DMI, kg/d & $24.1^{\mathrm{b}}$ & $23.8^{\mathrm{b}}$ & $25.0^{\mathrm{a}}$ & 0.49 \\
DE intake, Mcal/d & $64.7^{\mathrm{b}}$ & $64.4^{\mathrm{b}}$ & $69.3^{\mathrm{a}}$ & 1.32 \\
Milk, kg/d & $39.0^{\mathrm{b}}$ & $39.0^{\mathrm{b}}$ & $42.6^{\mathrm{a}}$ & 1.30 \\
Milk/DMI & $1.62^{\mathrm{b}}$ & $1.62^{\mathrm{b}}$ & $1.71^{\mathrm{a}}$ & 0.03 \\
Milk fat, \% & 3.85 & 3.85 & 3.75 & 0.097 \\
Milk fat, kg/d & $1.47^{\mathrm{b}}$ & $1.49^{\mathrm{b}}$ & $1.59^{\mathrm{a}}$ & 0.04 \\
Milk protein, \% & 2.92 & 2.89 & 2.93 & 0.032 \\
Milk protein, kg/d & $1.12^{\mathrm{b}}$ & $1.11^{\mathrm{b}}$ & $1.24^{\mathrm{a}}$ & 0.013 \\
Milk lactose, \% & $4.70^{\mathrm{ab}}$ & $4.68^{\mathrm{b}}$ & $4.72^{\mathrm{a}}$ & 0.031 \\
Milk lactose, kg/d & $1.82^{\mathrm{b}}$ & $1.79^{\mathrm{b}}$ & $2.01^{\mathrm{a}}$ & 0.045 \\
MUN, mg/dL & 9.49 & 9.3 & 9.27 & 0.202 \\
BCS & 2.8 & 2.8 & 2.9 & 0.09 \\
Body fat cover, cm & 0.79 & 0.76 & 0.77 & 0.021 \\
\hline
\end{tabular}

${ }^{\mathrm{a}, \mathrm{b}}$ Means within a row differ $(P<0.05)$.

${ }^{1}$ Statistical model included treatment, time, and time by treatment interaction. No time by treatment interactions were observed $(P>0.15)$.

${ }^{2}$ Digestible energy (DE) intake was calculated as individual DMI times treatment average measured DE concentration (Table 4). 


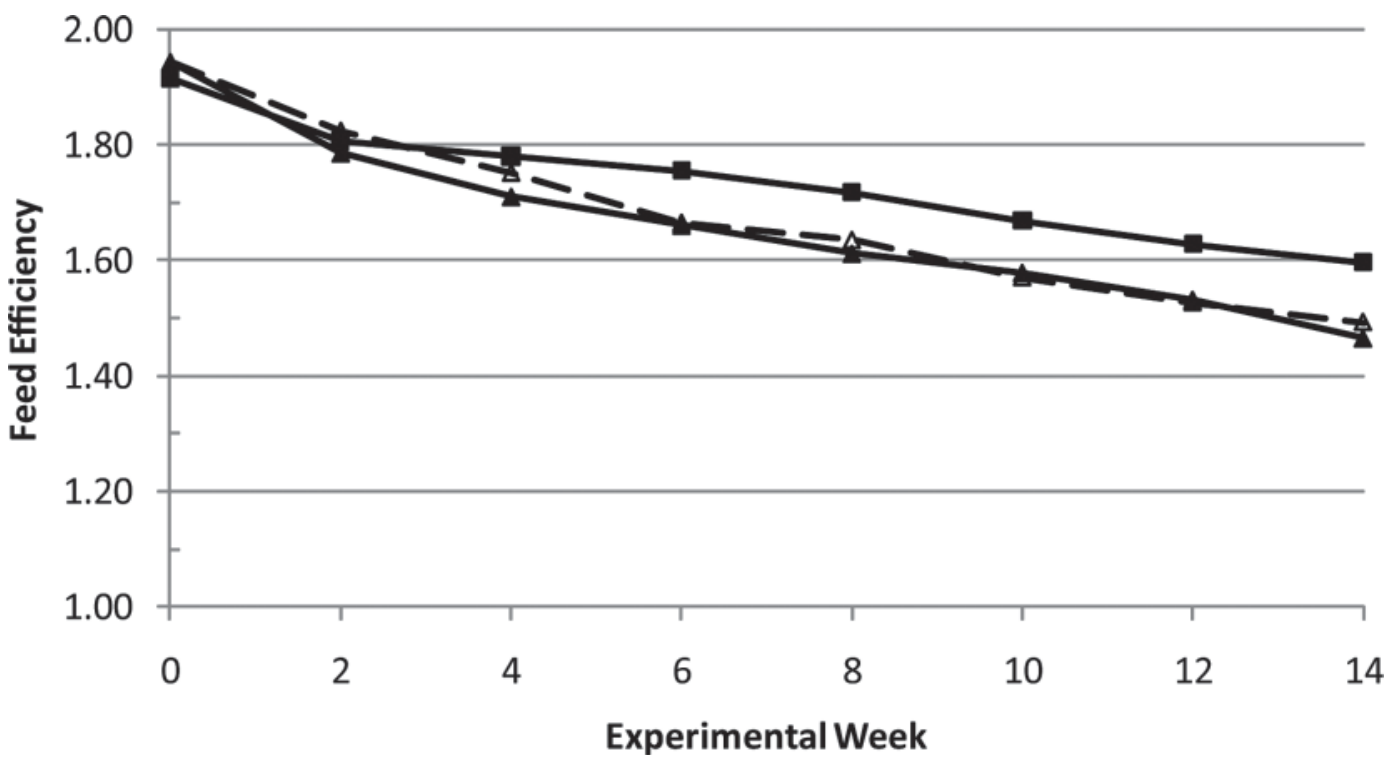

Figure 1. Gross feed efficiency (milk yield/DMI) over time by cows fed diets with $26 \%$ starch with (dashed line) or without (solid triangles) added amylase or a diet with $31 \%$ starch (solid squares). During wk 0, cows were fed a preliminary diet and treatment diets started on wk 1 . Average DIM at the start of wk 0 was 74 . Efficiency was greater $(P<0.05)$ for cows fed the high starch diet, and a time by treatment interaction was present $(P<0.05)$. SEM for each time-treatment mean $=0.047$.

digestibility of NDF usually decreases as DMI increases (Huhtanen et al., 2009).

The enzyme used in this study is a mono-component amylase. Klingerman et al. (2009) reported that this enzyme preparation had no detectable in vitro cellulase activity and extremely low xylanase activity. When a predominantly proteolytic enzyme (i.e., no detectable fibrolytic activity) was added to a TMR fed to dairy cows, digestibility of NDF also increased (Eun and Beauchemin, 2005). The authors suggested the enzyme might be digesting cell wall protein, allowing increased access to the fiber components of the cell wall. Beauchemin et al. (2004) hypothesized that exogenous enzymes in ruminant diets increased the overall hydrolytic capacity of the rumen because of increased bacterial populations and enhanced bacterial attachment to feed particles. Increasing the sugar concentration of diets in some studies increased in vivo NDF digestibility (Hristov and Ropp, 2003; Broderick and Radloff, 2004). Amylase did not increase the sugar concentration in the concentrates $(6.5$ and $6.7 \%$ of DM for control and enzyme treated, data not shown), but may have increased the concentration of sugars in the rumen. This will need to be evaluated in future studies.

\section{Production Study}

Only 3 treatments (low starch with and without enzyme and high starch without enzyme) were used in the production study because our primary objective was to determine whether enzyme addition to a low starch diet would result in similar production as the high starch diet when coarsely ground corn was fed. No differences were observed in any production measure between cows fed the low starch with or without added amylase. Gencoglu et al. (2010) reported that feeding the enzyme used in the present study decreased DMI, did not affect milk yield, and increased feed efficiency. Klingerman et al. (2009) also reported greater feed efficiency when this enzyme was fed but the enzyme tended to increase DMI and increased milk yields. In the current study, addition of the enzyme had no effect on feed efficiency. Diets in this study were higher in forage NDF (Table 1) than diets in those 2 studies and the high forage NDF probably limited DMI. Both studies (Klingerman et al., 2009; Gencoglu et al., 2010) that showed increased feed efficiency when this enzyme was fed used diets that had greater concentrations of high fiber byproduct feeds than in our diets.

Cows fed the high starch diet had greater DMI $(P$ $<0.05)$ than cows fed either of the low starch diets (Table 5). The higher DMI with greater DE concentration resulted in greater milk yields $(P<0.05)$ and feed efficiency $(P<0.05)$ by cows fed high starch compared with cows fed the low starch diets (Table 5). The treatment effect on feed efficiency required several weeks before becoming evident (treatment $\times$ time interaction; $P<0.01$ ) but then it was maintained through the end of the experiment (Figure 1). 

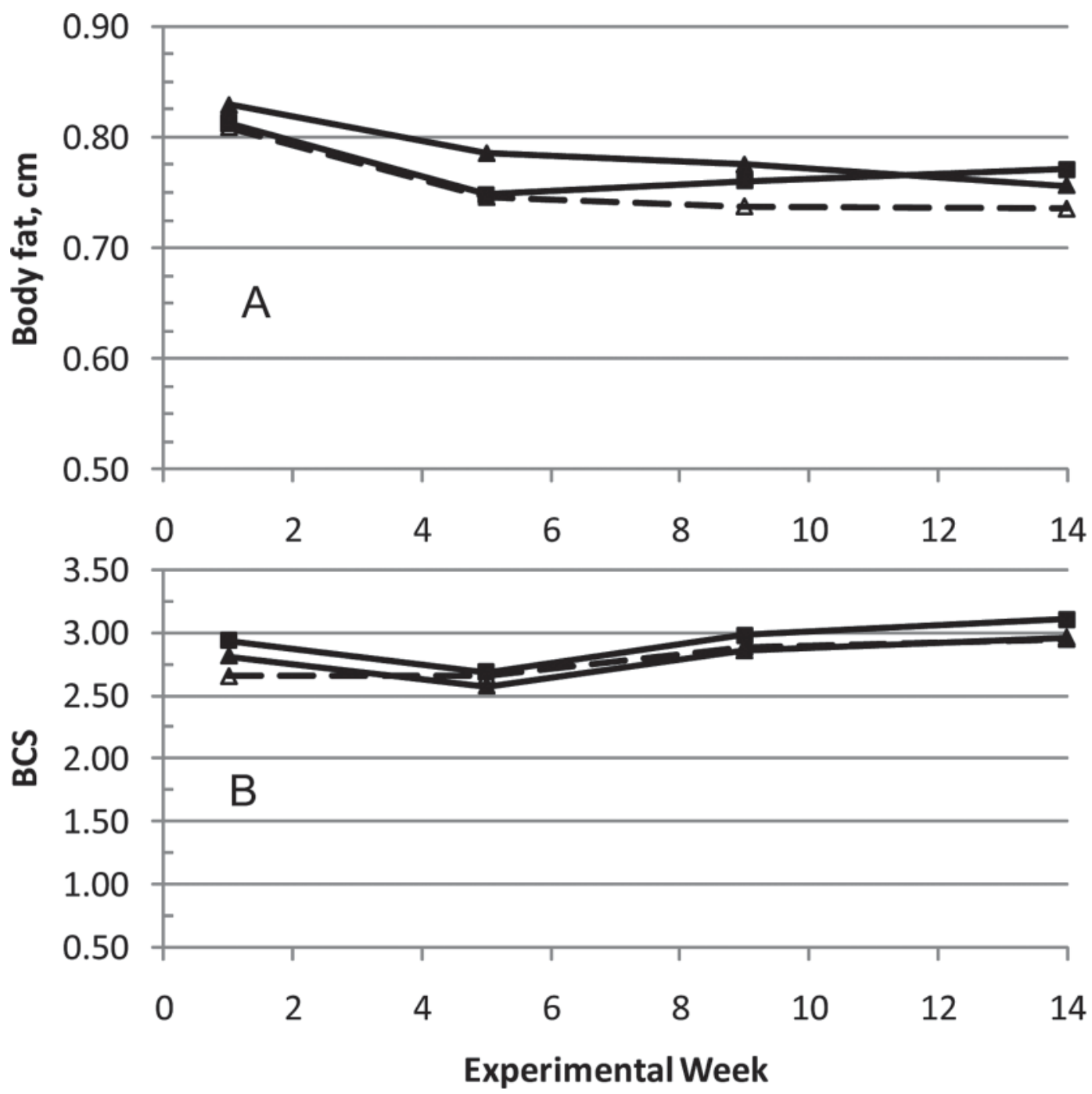

Figure 2. Body fat cover (A) and BCS (B) over time of cows fed diets with $26 \%$ starch with (dashed line) or without (solid triangles) added amylase or a diet with $31 \%$ starch (solid squares). During wk 0, cows were fed a preliminary diet and treatment diets started on wk 1. Average DIM at the start of wk 0 was 74 . No treatment or treatment $\times$ time interactions were observed. SEM for each time-treatment mean $=0.11$ for BCS and 0.025 for fat.

Milk fat concentration was not decreased with the high starch diet, suggesting that rumen $\mathrm{pH}$ and rumen fermentation were not adversely affected by the decrease in NDF and increase in starch concentrations. Milk fat and protein yields were greater $(P<0.05)$ when cows were fed the high starch diet. The increased yield of milk protein is probably a result of the increased intake of DE (DePeters and Cant, 1992). Lactose concentration was affected by treatment $(P<0.05)$ but the actual differences were quite small (Table 5 ). The concentration of MUN was not affected by treatment (Table 5) even though replacing NDF with starch can decrease MUN (Weiss et al., 2009). Milk urea $\mathrm{N}$ averaged $9.4 \mathrm{mg} / \mathrm{dL}$, which is low but within the established target range
(Kohn et al., 2002). The lack of a decrease in MUN to increasing starch may mean that RDP, rather than fermentable carbohydrate, was the limiting factor.

Using the measured DE concentrations from the digestion study (Table 4), cows fed the high starch diet consumed approximately $4.8 \mathrm{Mcal} / \mathrm{d}$ more DE than cows fed the low starch diets $(P<0.01$; Table 5$)$. That amount of DE should support approximately $3.4 \mathrm{~kg}$ of milk (NRC, 2001) compared with the measured difference of $3.6 \mathrm{~kg} / \mathrm{d}$. This suggests that essentially all the increase in DE intake when cows were fed the high starch diet was partitioned toward milk. The lack of any difference in BCS or body fat measurements (Table 5; Figure 2) also supports that conclusion. 


\section{CONCLUSIONS}

Adding amylase to a concentrate mix based on coarsely ground corn (mean particle size $=1.4 \mathrm{~mm}$ ) did not affect milk production or digestibility of energy or starch, but consistent with previous studies, it increased NDF digestibility. Replacing forage NDF with starch from coarsely ground corn increased DMI and energy digestibility, resulting in a substantial increase in $\mathrm{DE}$ intake, which in a long-term study increased milk yield. Overall, a low starch diet high in forage NDF that included coarsely ground corn and an exogenous amylase was not nutritionally equivalent to a high starch diet.

\section{ACKNOWLEDGMENTS}

Salary and research support was provided by state and federal funds appropriated to the Ohio Agricultural Research and Development Center, The Ohio State University, Manuscript 18-10AS. Additional financial support was provided by DSM Nutritional Products Ltd. (Basel, Switzerland).

\section{REFERENCES}

Allen, M. S. 2000. Effects of diet on short-term regulation of feed intake by lactating dairy cows. J. Dairy Sci. 83:1598-1624.

Association of Official Analytical Chemists. 2000. Official Methods of Analysis. Vols. 1 and 2. 17th ed. AOAC Int., Gaithersburg, MD.

Beauchemin, K. A., D. Colombatto, D. P. Morgavi, W. Z. Yang, and L. M. Rode. 2004. Mode of action of exogenous cell wall degrading enzymes for ruminants. Can. J. Anim. Sci. 84:13-22.

Bowman, G. R., K. A. Beauchemin, and J. A. Shelford. 2002. The proportion of the diet to which fibrolytic enzymes are added affects nutrient digestion by lactating dairy cows. J. Dairy Sci. 85:3420-3429

Broderick, G. A., and W. J. Radloff. 2004. Effect of molasses supplementation on the production of lactating dairy cows fed diets based on alfalfa and corn silage. J. Dairy Sci. 87:2997-3009.

DePeters, E. J., and J. P. Cant. 1992. Nutritional factors influencing the nitrogen composition of bovine milk: A review. J. Dairy Sci. 75:2043-2070.

Eun, J. S., and K. A. Beauchemin. 2005. Effects of a proteolytic feed enzyme on intake, digestion, ruminal fermentation, and milk production. J. Dairy Sci. 88:2140-2153.

Firkins, J. L., M. L. Eastridge, N. R. St-Pierre, and S. M. Noftsger. 2001. Effects of grain variability and processing on starch utilization by lactating dairy cows. J. Anim. Sci. 79(E-Suppl.):E218E238.

Gencoglu, H., R. D. Shaver, W. Steinberg, J. Ensink, L. F. Ferraretto, S. J. Bertics, J. C. Lopes, and M. S. Akins. 2010. Effect of feeding a reduced-starch diet with or without amylase addition on lactation performance in dairy cows. J. Dairy Sci. 93:723-732.
Gutiérrez, C., G. D. Mendoza, R. Ricalde, L. M. Melgoza, and F. Plata. 2005. Effect of exogenous amylase or glucoamylase dose on in situ ruminal digestion of corn and sorghum. J. Appl. Anim. Res. 27:7-10.

Hristov, A. N., C. E. Basel, A. Melgar, A. E. Foley, J. K. Ropp, C. W. Hunt, and J. M. Tricarico. 2008. Effect of exogenous polysaccharide-degrading enzyme preparations on ruminal fermentation and digestibility of nutrients in dairy cows. Anim. Feed Sci. Technol. 145:182-193.

Hristov, A. N., and J. K. Ropp. 2003. Effect of dietary carbohydrate composition and availability on utilization of ruminal ammonia nitrogen for milk protein synthesis in dairy cows. J. Dairy Sci. 86:2416-2427.

Huhtanen, P., M. Rinne, and J. Nousiainen. 2009. A meta-analysis of feed digestion in dairy cows. 2 . The effects of feeding level and diet composition on digestibility. J. Dairy Sci. 92:5031-5042.

Kerley, M. S., J. L. Firkins, J. G. C. Fahey, and L. L. Berger. 1985. Roughage content and particle size: Their effect on size reduction and fiber composition of particles passing through the gastrointestinal tract of sheep fed corncob-concentrate diets. J. Dairy Sci. 68:1363-1369.

Klingerman, C. M., W. Hu, E. E. McDonell, M. C. DerBedrosian, and L. Kung Jr. 2009. An evaluation of exogenous enzymes with amylolytic activity for dairy cows. J. Dairy Sci. 92:1050-1059.

Kohn, R. A., K. F. Kalscheur, and E. Russek-Cohen. 2002. Evaluation of models to estimate urinary nitrogen and expected milk urea nitrogen. J. Dairy Sci. 85:227-233.

Lammers, B. P., D. R. Buckmaster, and A. J. Heinrichs. 1996. A simple method for the analysis of particle sizes of forage and total mixed rations. J. Dairy Sci. 79:922-928.

National Research Council. 2001. Nutrient Requirements of Dairy Cattle. 7th rev. ed. Natl. Acad. Press, Washington, DC.

Reece, F. N., B. D. Lott, and J. W. Deaton. 1986. Effects of environmental temperature and corn particle size on response of broilers to pelleted feed. Poult. Sci. 65:636-641.

Rode, L. M., W. Z. Yang, and K. A. Beauchemin. 1999. Fibrolytic enzyme supplements for dairy cows in early lactation. J. Dairy Sci. $82: 2121-2126$

Rojo, R., G. D. Mendoza, S. S. Gonzalez, L. Landois, R. Barcena, and M. M. Crosby. 2005. Effects of exogenous amylases from Bacillus licheniformis and Aspergillus niger on ruminal starch digestion and lamb performance. Anim. Feed Sci. Technol. 123-124:655-665.

SAS Institute. 2004. SAS/STAT User's Guide. Version 9. SAS Institute Inc., Cary, NC.

Schröder, U. J., and R. Staufenbiel. 2006. Methods to determine body fat reserves in the dairy cow with special regard to ultrasonographic measurement of backfat thickness. J. Dairy Sci. 89:1-14.

Weiss, W. P., N. R. St-Pierre, and L. B. Willett. 2009. Varying type of forage, concentration of metabolizable protein, and source of carbohydrate affects nutrient digestibility and production by dairy cows. J. Dairy Sci. 92:5595-5606.

Weiss, W. P., and D. J. Wyatt. 2000. Effect of oil content and kernel processing of corn silage on digestibility and milk production by dairy cows. J. Dairy Sci. 83:351-358.

Wilkerson, V. A., B. P. Glenn, and K. R. McLeod. 1997. Energy and nitrogen balance in lactating cows fed diets containing dry or high moisture corn in either rolled or ground form. J. Dairy Sci. 80:2487-2496.

Yang, W. Z., K. A. Beauchemin, and L. M. Rode. 1999. Effects of an enzyme feed additive on extent of digestion and milk production of lactating dairy cows. J. Dairy Sci. 82:391-403. 